\title{
Shrub-grassland small mammal and vegetation responses to rest from grazing
}

\author{
STEVEN S. ROSENSTOCK
}

\begin{abstract}
Author is research biologist, Arizona Game and Fish Department, 2221 W. Greenway Rd, Phoenix, Ariz. 85023. At the time this study was conducted, he was independent consultant, dba Wingate Eco-Logic, P.O. Box 462, Fredonia, Ariz. 86022 .
\end{abstract}

\begin{abstract}
Between 1989-1991, I studied the effects of livestock grazing on vegetation and small mammals in semiarid shrub-grassland habitats of south-central Utah. Responses were measured at 2 spatial habitat scales; patches and macrohabitats. Patch-scale data were obtained from 4 small $(<1 \mathrm{ha})$ livestock exclosures and nearby grazed areas. Macrohabitat-scale data were collected at 4 actively grazed sites and $\mathbf{4}$ comparable, excellent condition sites, ungrazed for 30+ years. Ungrazed patch and macrohabitat sites had more surface litter, greater perennial grass cover, and taller perennial grass plants, but treatment response varied among sites. Small mammal responses were apparent only at the macrohabitat scale, where ungrazed sites had 50\% greater species richness and $80 \%$ higher abundance. Small mammal reproductive activity and biomass were not affected by rest from grazing at either scale. Small mammal community composition varied greatly among sites and within treatments. This variability has important implications for ecological monitoring efforts involving these species.
\end{abstract}

Key Words: small mammals, grazing effects, scale, Colorado Plateau

Livestock grazing has been a pervasive influence on shrubgrassland communities of the Intermountain United States (West 1988). Previous studies have shown that livestock grazing can significantly affect the floristic composition and vegetative structure of these habitats (Kleiner and Harper 1972, Tuhy and MacMahon 1988). Recently, considerable attention has been focused on the effects of livestock grazing on faunal abundance and diversity in arid rangelands (Fleischner 1994).

Because small mammal communities can be sampled relatively easily, they have been used as indicators to monitor ecosystem responses to management (Douglass 1984, OIson et al. 1994). Small mammals may also be useful ecological units with which to examine the effects of grazing on biodiversity in arid environments. Small mammals select habitat at multiple spatial scales;

Research was supported by the U.S. Department of the Interior, National Park Service. Valuable assistance was provided by Norm Henderson, Mike Bogan, Susi MacVean, Tim Graham, David Willey, and Bill Booker. The author thanks Brian Wakeling and 3 anonymous reviewers for constructive comments on earlier versions of this manuscript.

Manuscript accepted 11 Sept. 1995. microhabitats, patches, and macrohabitats (Price 1978, Brown 1987), and are strongly influenced by habitat structure (Rosenzweig and Winakur 1969, Bowers and Flanagan 1988). Selection is typically for habitat components providing favorable microclimates, food, cover, and avoidance of competitors (Brown 1989, Brown et al. 1988); many of which can be directly or indirectly affected by grazing.

Small mammal responses to grazing in shrub-grasslands of the Colorado Plateau have not been previously described. To address this information gap, I examined changes in shrub-grassland vegetation and small mammal communities, following rest from grazing. I measured small mammal community and demographic parameters at 2 spatial habitat scales, patches and macrohabitats. These scales reflected distinct changes to which small mammals might respond. Patches were defined as isolated ungrazed sites $>1$ ha, smaller than the home ranges of resident small mammal species. If ungrazed patches provided more resources (food or cover) than available in the surrounding grazed area, they should receive greater small mammal use. Animals using these patches could also have a higher level of reproductive activity during the breeding season. I also hypothesized that similar responses would occur at a macrohabitat scale. I defined macrohabitats as extensive tracts ( $>100 \mathrm{ha}$ ) of the same shrub-grassland habitat, large enough to contain the home ranges of numerous small mammals.

\section{Methods}

\section{Study Areas}

Study sites were located in Capitol Reef National Park ( $38^{\circ} 15^{\prime \prime}$ $\mathrm{N} 111^{\circ} 15^{\prime} \mathrm{W}$ ), Canyonlands National Park ( $38^{\circ} 15^{\circ} \mathrm{N} 109^{\circ} 55^{\prime \prime}$ $\mathrm{W}$, and adjacent lands administered by the Bureau of Land Management (BLM), in Wayne and Grand Counties, south-central Utah, the northwest portion of the Colorado Plateau. The climate of this area is semiarid, temperate continental, with average annual precipitation of $17 \mathrm{~cm}$ per year (U.S. Weather Bureau, Climate and Precipitation Summaries, Utah). Study sites were located on Semidesert Sandy Loam range sites (USDA Soil Conservation Service, Unpublished data), and were dominated by cool-season bunchgrasses (primarily Stipa hymenoides and $S$. comata), warm-season sod-forming grasses (primarily Hilaria jamesii and Bouteluoa gracilis), and low-medium stature shrubs of several genera (primarily Gutierrizia, Ceratoides and Atriplex). Detailed descriptions of these plant communities can be found in Romme et al. (1993). 
Patch-scale data were collected at 4 livestock exclosures previously established in Capitol Reef. Three were relatively recent (approximately 6 years old) and therefore reflected short-term rest from grazing pressure. The fourth exclosure was established in 1951. Exclosures were $0.1-0.8$ ha in size and located within large ( $\geq 100 \mathrm{ha}$ ), contiguous tracts of shrub-grassland. All were in active grazing allotments, managed under a deferred system. The allotments comprised 35,499 ha within Capitol Reef and supported approximately 1,500 permitted AUM's of fall-spring (October-May) grazing by cattle each year. These allotments were classified in "fair" (mid-seral) range condition (USDA Soil Conservation Service, Unpublished 1990 data).

Macrohabitat-scale data were collected at 8 sites, 4 grazed sites in Capitol Reef, 2 ungrazed sites in Canyonlands, and 2 ungrazed sites on adjacent BLM lands. Study sites were selected to match geologic and edaphic factors as closely as possible. All represented large ( $\geq 100 \mathrm{ha}$ ) contiguous tracts of shrub-grassland. Ungrazed sites were historically heavily used by cattle, but had been ungrazed for $30+$ years, and were rated in excellent (lateseral) range condition (Anonymous 1980; Tim Graham, Canyonlands Nat. Park, pers. comm.). Grazed macrohabitat sites in Capitol Reef were located within the same allotments as the exclosures.

\section{Habitat Measurements}

Habitat characteristics were measured at all study areas in 1990. Understory vegetation was sampled on 5 randomly located line intercept transects within each trap grid. Because I was interested primarily in gross habitat composition and structure, understory components were grouped into 5 categories (annual forbs, perennial forbs, annual grasses, perennial grasses, and litter). Canopy cover was estimated within two $0.1-\mathrm{m}^{2}$ quadrats placed every $5 \mathrm{~m}$ on either side of the transect. Within each quadrat, I also measured the maximum height of standing perennial grasses. Shrub cover and density were sampled on 4 separate line intercept transects randomly located within each grid. Understory and shrub transects were $25 \mathrm{~m}$ in length at exclosures, and $50 \mathrm{~m}$ long at macrohabitat sites.

\section{Small Mammal Sampling}

Small mammals were trapped using grids of live traps (type LFV, dimensions $=7.6 \mathrm{~cm} \times 7.6 \mathrm{~cm} \times 22.9 \mathrm{~cm}$, H.B. Sherman Traps, Inc., Tallahassee, Fla.). Exclosure grids were square or rectangular, with traps spaced $5 \mathrm{~m}$ apart. Grid size was proportional to exclosure size, and ranged from 25-64 traps. Two trap grids were established at each exclosure. One was located inside, with a 5-m buffer from the fence. An identical grid was randomly placed $>500 \mathrm{~m}$ away in the grazed area, to ensure sampling independence. One square, 8 by 8 grid, with 10-m trap spacing was randomly located at each macrohabitat site.

Each grid was trapped once per year, for 4 consecutive days, between 1 May and 31 June. Exclosures were sampled 1989-91, 3 for all 3 years and 1 for the last 2 years. Exclosure and adjacent grazed grids were sampled simultaneously. Macrohabitat sites were sampled in 1990 only. Traps were baited with a mixture of rolled oats, peanut butter, and birdseed. A ball of raw wool, approximately $7 \mathrm{~cm}$ in diameter was placed in each trap for bedding material and protective insulation. Traps were checked shortly after sunrise, at noon, and before sunset.
Captured small mammals were identified to species, sexed, and weighed to the nearest gram using a Pesola ${ }^{\mathrm{TM}}$ hand-held scale. Breeding condition was determined from external characteristics, with individuals having scrotal testes or swollen mammae classified as reproductively active. Each animal was fitted with a numbered metal ear tag (Style 1005-1, National Band and Tag Co., Newport, Ky.) to facilitate subsequent identification. Trapped animals were released at the point of capture.

\section{Data Analysis}

I tested the effects of rest from grazing on 8 habitat variables: the percent cover of litter, annual forbs, perennial forbs, annual grasses, perennial grasses, and shrubs; grass height; and shrub density. Patch-scale data were analyzed using factorial Analysis of Variance (Zar 1984), with treatment and site as main effects. Habitat data from macrohabitat sites were analyzed with t-tests.

I calculated 3 small mammal response variables from trapping data obtained on each grid: 1) species richness (total number of species), 2) an abundance index (number of individuals captured per 100 trap days of sampling effort), and 3) a reproductive activity index (proportion of captured individuals in reproductive condition). Capture sample sizes were too small to test individual species' response to grazing. Therefore, abundance and reproduction were assessed for the entire small mammal community, by pooling values for all species trapped on a grid. At patch scale, abundance index values were interpreted as a relative measure of the number of individuals using the sampled area, rather than an estimate of actual abundance. For macrohabitat sites, I also calculated total small mammal biomass/grid, by summing the weights of all trapped individuals. The effective sampling radius of trap grids likely extended beyond the outer line of traps. However, because this distance was unknown, I used the area of the grid itself to calculate a relative measure of biomass/ha.

A paired t-test (Zar 1984) was used to compare small mammal response variables between ungrazed exclosures and grazed comparison grids across all sites and years. Differences between grazed and ungrazed macrohabitat sites were analyzed with a randomization test (Manly 1991). Results of all statistical tests were considered significant at $P \leq 0.05$.

I calculated Jaccard's Index ( $\left.\mathrm{J}_{i}\right)$ (Ludwig and Reynolds 1988) from species presence/absence, as a measure of small mammal community similarity between grids. This index yields values ranging from 0 (total dissimilarity in species composition) to 1 (complete overlap). Index values were averaged to obtain a mean similarity for each combination of plot scale and grazing treatment.

\section{Results}

\section{Habitat Characteristics}

Grazing affected understory habitat characteristics at both scales of measurement (Table 1). Ungrazed patches had more perennial grass and litter cover, and taller perennial grass plants than the adjacent grazed area $(P \leq 0.001)$. However, site $\times$ treatment interactions were significant $(P \leq 0.001)$ for the latter 2 variables. Ungrazed macrohabitat sites also had greater litter and perennial grass cover, and taller perennial grass plants than grazed sites $(P \leq 0.001)$. Grazed macrohabitat sites also had greater cover of annual forbs $(P \leq 0.05)$, primarily Russian thistle (Salsola kali). Shrub cover and density were unaffected by grazing treatment at either scale. 
Table 1. Habitat characteristics (mean \pm SE) of ungrazed and grazed patch and macrohabitat shrub-grassland study plots. Significant treat-

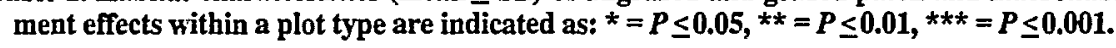

\begin{tabular}{|c|c|c|c|c|}
\hline \multirow[b]{2}{*}{ Variable } & \multicolumn{2}{|c|}{ Patch Plots } & \multicolumn{2}{|c|}{ Macrohabitat Plots } \\
\hline & Ungrazed & Grazed & Ungrazed & Grazed \\
\hline litter cover $(\%)$ & $10.07 \pm 0.03^{* * *}$ & $3.45 \pm 1.10$ & $3.57 \pm 0.28^{* * *}$ & $1.21 \pm 0.08$ \\
\hline annual forb cover (\%) & $0.11 \pm 0.03$ & $0.16 \pm 0.04$ & $0.37 \pm 0.10^{*}$ & $0.95 \pm 0.20$ \\
\hline perennial forb cover (Co) & $0.44 \pm 0.19$ & $0.22 \pm 0.06$ & $0.30 \pm 0.08$ & $0.12 \pm 0.05$ \\
\hline annual grass cover $(\mathscr{C})$ & $0.24 \pm 0.12$ & $0.08 \pm 0.04$ & $\mathbf{t r}^{\mathbf{l}}$ & $\mathbf{t r}^{1}$ \\
\hline perennial grass cover $(\%)$ & $9.35 \pm 0.68^{* * *}$ & $1.45 \pm 0.23$ & $11.93 \pm 0.68^{* * *}$ & $4.66 \pm 0.65$ \\
\hline grass height $(\mathrm{cm})$ & $23.48 \pm 1.78^{* * *}$ & $13.98 \pm 1.19$ & $35.86 \pm 1.34^{* * *}$ & $14.59 \pm 1.31$ \\
\hline shrub cover $(\%)$ & $8.06 \pm 1.59$ & $6.89 \pm 1.03$ & $6.78 \pm 0.75$ & $7.09 \pm 0.90$ \\
\hline shrub density $\left(\# / \mathrm{m}^{2}\right)$ & $0.22 \pm 0.04$ & $0.26 \pm 0.04$ & $0.14 \pm 0.02$ & $0.19 \pm 0.03$ \\
\hline
\end{tabular}

${ }^{1}$ Present in trace amounts only $(\$ 0.5 \%)$

\section{Small Mammals}

A total of 6,848 trap-days of sampling (4,800 at patch plots, 2,048 at exclosures) yielded 113 individuals, representing 6 small mammal species: white-tailed antelope squirrel (Ammospermophilus leucurus), Ord's kangaroo rat (Dipodomys ordii), northern grasshopper mouse (Onychomys leucogaster), deer mouse (Peromyscus maniculatus), pinyon mouse ( $P$. truei), and Great Basin pocket mouse (Perognathus parvus).

Small mammal species composition varied between and within scales and treatments (Table 2). Except for ungrazed macrohabi-
Small mammal species richness was not affected by grazing treatment at patch scale, but was slightly higher $(P \leq 0.01)$ on ungrazed versus ungrazed macrohabitat sites (Table 3). Overall small mammal abundance (all species combined) was not affected by grazing at patch scale, but was higher $(P \leq 0.05)$ on ungrazed versus grazed macrohabitat sites (Table 3 ). Rest from grazing had no effect on small mammal reproductive condition at either scale, or on total small mammal biomass at macrohabitat sites (Table 3).

Table 2. Small mammal similarity between ungrazed and grazed shrub-grassland patch and macrohabitat study plots. Values are means \pm SE of pairwise Jaccard Index values.

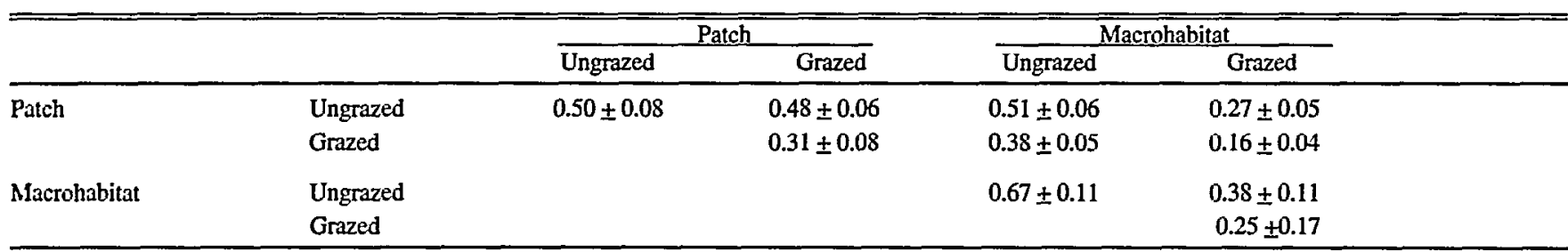

tats, species composition of plots within a scale and treatment was highly variable (diagonal elements of Table 2). Grazed and ungrazed plots at both scales also had low similarity. Between scales, ungrazed patches and macrohabitats had the highest similarity $\left(\mathrm{J}_{i}=0.51\right)$, while grazed patches and microhabitats had the lowest similarity.

Table 3. Small mammal species richness, overall abundance, reproductive condition and biomass (means $\pm \mathrm{SE}$ ) on ungrazed and grazed, patch and macrohabitat shrub-grassland study plots. Asterisks indicate significant $(P \leq 0.05)$ treatment effects within a plot type.

\begin{tabular}{|c|c|c|c|c|}
\hline $\begin{array}{l}\text { Plot Type } \\
\text { treatment }\end{array}$ & $\begin{array}{c}\text { Species } \\
\text { Richness }\end{array}$ & Abundance & $\begin{array}{l}\text { Proportion } \\
\text { Reproductive } \\
\text { Active }\end{array}$ & Biomass \\
\hline & & \multicolumn{2}{|c|}{ (no/100 trap-days) } & $(\mathrm{gm} / \mathrm{ha})$ \\
\hline $\begin{array}{l}\text { Patch } \\
\text { ungrazed } \\
\text { grazed }\end{array}$ & $\begin{array}{l}1.45 \pm 0.16 \\
1.63 \pm 0.20\end{array}$ & $\begin{array}{l}1.85 \pm 0.47 \\
2.26 \pm 0.37\end{array}$ & $\begin{array}{l}0.50 \pm 0.14 \\
0.59 \pm 0.11\end{array}$ & \\
\hline $\begin{array}{l}\text { Macrohabitat } \\
\text { ungrazed } \\
\text { grazed }\end{array}$ & $\begin{array}{l}1.50 \pm 0.29 * \\
1.00 \pm 0.25\end{array}$ & $\begin{array}{l}1.76 \pm 0.47^{*} \\
0.98 \pm 0.12\end{array}$ & $\begin{array}{l}0.79 \pm 0.12 \\
0.79 \pm 0.13\end{array}$ & $\begin{array}{l}125.34 \pm 34.75 \\
125.49 \pm 40.16\end{array}$ \\
\hline
\end{tabular}

Species' abundance in grazed versus ungrazed plots varied between scales (Table 4). The dominant species (Great Basin pocket mice and deer mice) were more abundant on grazed versus ungrazed patch plots, a pattern was which was reversed at macrohabitat scale. Similarly, Ord's kangaroo rats were caught most frequently on ungrazed patch plots, but were absent from ungrazed macrohabitat plots.

\section{Discussion}

Herbaceous vegetation showed a strong response to rest from grazing, paralleling results of other studies of Colorado Plateau shrub-grasslands (Kleiner 1983, West 1983). The ungrazed macrohabitat sites sampled in my study resembled nearby relict areas described as having "lush bunchgrass physiognomy" (Tuhy and MacMahon 1988:289). Vegetation responses to rest from grazing varied among sites, likely in response to unmeasured differences in livestock utilization, soils, or other site characteristics.

The variation in small mammal community composition at both scales was likely attributable to local biogeographic influences 
Table 4. Small mammal abundance (range, mean $\pm S E$ ) on ungrazed and grazed patch and macrohabitat shrub-grassland study plots.

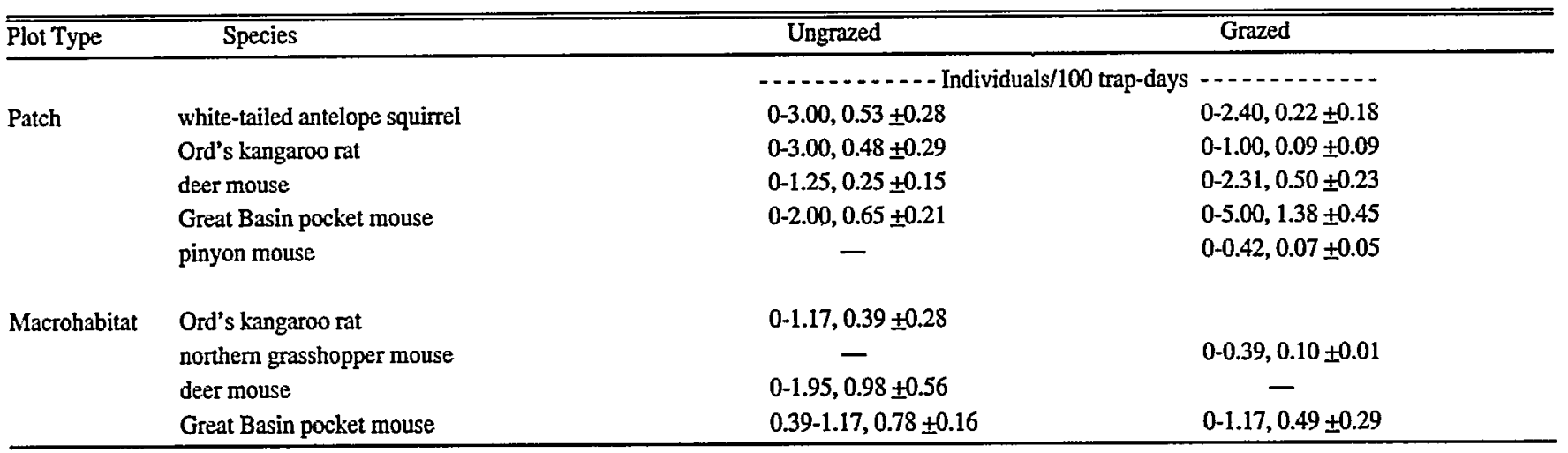

and population processes. Desert rodent communities are characterized by high spatial and temporal variability (Brown and Kurzius 1989). Small mammal populations also exhibit largemagnitude, geographically asynchronous fluctuations, including temporary local extinctions (Brown and Zeng 1989).

The lack of grazing effects at patch scale probably reflected the small size and isolation of ungrazed patches, which may not have provided enough suitable habitat to facilitate a detectable difference in overall small mammal use or reproductive activity (Brown 1987). There was however, evidence to suggest that both grazed and ungrazed patches were more heavily used by some small mammal species. Studies conducted in other arid western rangelands have reported that deer mice are generally more abundant on grazed sites (Larrison and Johnson 1973, Hanley and Page 1982), while Great Basin pocket mice and Ord's kangaroo rats show variable responses to grazing (Black and Frischknecht 1971, O'Connell 1979, Whitford et al. 1978, Hanley and Page 1982).

The slightly higher small mammal species richness and abundance on ungrazed macrohabitat sites could be a response to the increased perennial grass cover and aboveground biomass, which would provide more food and cover. Conversely, on grazed sites, livestock use could directly impact small mammal populations, by trampling burrows and compacting the soil (Heske and Campbell 1991). Because my sample sizes were small and reflected a narrow time frame, these results should be viewed as hypotheses in need of further testing.

The observed lack of difference in small mammal biomass between grazed and ungrazed macrohabitat sites indicates that factors other than the measured habitat variables affect the carrying capacity of these shrub-grasslands. Grant et al. (1982) also found similar small mammal biomass at grazed and ungrazed sites in more mesic bunchgrass and shortgrass prairie habitats.

\section{Conclusions}

The shrub-grasslands I studied appear resilient, responding to rest from grazing within relatively short time frames. In particular, the excellent condition macrohabitat study areas were once heavily grazed, but after 25-30 years of rest, appeared physiognomically similar to relict areas elsewhere on the Colorado Plateau. Associated small mammal communities had low densities and species richness, but seemed to respond to rest from grazing. Additional research is needed to more rigorously test these effects and evaluate species-specific responses to grazinginduced habitat changes.

The spatial and temporal variability of these small mammal communities suggests extreme caution in their use as indicators of ecosystem change. Response data would be highly site-specific, and could only be interpreted against a long-term baseline, likely beyond the scope of most monitoring efforts. In addition, one would need to control for, or at least have a solid understanding of the many factors affecting small mammal distribution, habitat use, abundance, and demographics.

\section{Literature Cited}

Anonymous. 1980. Soil/Vegetation Inventory, Henry Mountain Planning Unit, Utah, Vol. II. Contract Rep. YA-512-CT9-149, USDI Bureau of Land Management, Hanksville, Ut.

Black, H.C. and N.C. Frischknecht. 1971. Relative abundance of mice on seeded sagebrush-grass range in relation to grazing. USDA For. Serv. Res. Note INT-147, Ogden, Ut.

Bowers, M.A. and C.A. Flanagan. 1988. Microhabitat as a template for the organization of a desert rodent community. pp. 300-312. In: R.C. Szaro, K.E. Severson, and D.R. Patton (tech. coords.), Management of amphibians, reptiles and small mammals in North America. USDA For. Serv. Gen. Tech. Rep. RM-166, Fort Collins, Colo.

Brown, J.H. 1987. Variation in desert rodent guilds: patterns, processes and scales. pp. 185-203. In: J.H.R. Gee and P.S. Giller (eds.), Organization of communities past and present. Blackwell Scientific Publ., Oxford.

Brown, J.H. and M.A. Kurzius. 1989. Spatial and temporal variation in guilds of North American granivorous desert rodents, p. 71-90. In: D.W. Morris, Z. Abramsky, B.J. Fox, and M.R. Willig (eds.), Patterns in the structure of mammalian communities. Texas Tech. Univ. Press, Lubbock.

Brown, J.H. and Z. Zeng. 1989. Comparative population ecology of eleven species of rodents in the Chihuahuan Desert. Ecol. 70:1507-1525.

Brown, J.S. 1989. Desert rodent community structure: a test of four mechanisms of coexistence. Ecol. Monogr. 59:1-20.

Brown, J.S., B.P. Kotler, R.J. Smith, and W.O. Wirtz. 1988. The effects of owl predation on the foraging behavior of heteromyid rodents. Oecol. 76:498-415.

Douglass, R.J. 1984. The use of rodents in monitoring ecological impacts of oil shale development in the Piceance Basin, Colorado, p. 70-75. In: R.L. Comer (ed.), Issues and technology in the management of impacted western wildlife. Thome Ecol. Inst., Boulder, Colo.

Fleischner, T.L. 1994. Ecological costs of livestock grazing in western North America. Conserv. Biol. 8:629-644. 
Grant, W.E., E.C. Birney, N.R. French, and D.M. Swift. 1982. Structure and productivity of grassland small mammal communities related to grazing-induced changes in vegetative cover. J. Mammal. 63:248-260.

Hanley, T.A. and J.L. Page. 1982. Differential effects of livestock use on habitat structure and rodent populations in Great Basin communities. Calif. Fish and Game 68:160-174.

Heske, E.J. and M. Campbell. 1991. Effects of an 11-year livestock exclosure on rodent and ant numbers in the Chihuahuan Desert, Southeastern Arizona. Southw. Nat. 36:89-93.

Kleiner, E.F. 1983. Successional trends in an ungrazed, arid grassland over a decade. J. Range Manage. 36:114-118.

Kleiner, E.F. and K.T. Harper. 1972. Environment and community organization of grasslands of Canyonlands National Park. Ecol. 53:299-309.

Larrison, E.J. and D.R. Johnson. 1973. Density changes and habitat affinities of rodents of shadscale and sagebrush associations. Great Basin Nat. 33:255-264.

Ludwig, J.A. and J.F. Reynolds. 1988. Statistical ecology: a primer on methods and computing. John Wiley and Sons, New York, N.Y.

Manly, B.F. 1991. Randomization and Monte Carlo methods in biology. Chapman and Hall, New York, N.Y.

O'Connell, M.A. 1979. Coexistence of two species of kangaroo rats (Genus Dipodomys) in the Guadeloupe Mountains National Park, Texas, p. 349-371. In: H.H. Genoways and R.J. Baker (eds.), Biological Investigations in the Guadeloupe Mountains National Park, Texas. Nat. Park Serv. Proc. and Trans. Ser. No. 4, Washington, D.C.
Olson, R., J. Hansen, T. Whitson, and K. Johnson. 1994. Tebuthiuron to enhance rangeland diversity. Rangelands 16:197-201.

Price, M.V. 1978. The role of microhabitat in structuring desert rodent communities. Ecol. 59:910-921.

Romme, W.H., K.D. Heil, J.M. Porter, and R. Fleming. 1993. Plant communities of Capitol Reef National Park, Utah. USDI National Park Serv. Tech. Rep. NPS/NAUCARE/NRTR-93/02. Coop. Studies Unit, Northern Arizona Univ., Flagstaff, Ariz.

Rosenzweig, M.L. and J. Winakur. 1969. Population ecology of desert rodent communities: habitats and environmental complexity. Ecol. 50:558-572.

Tuhy, J.S. and J.A. MacMahon. 1988. Vegetation and relict communities of Glen Canyon National Recreation Area. Rep. to Nat. Park Serv., Glen Canyon Nat. Recreation Area, Page, Ariz.

West, N.E. 1983. Southeastern Utah galleta-threeawn shrub steppe, p. 413-421. In: N.E. West (ed.), Temperate deserts and semi-deserts, Vol. 5, Ecosystems of the world. Elsevier, Amsterdam.

West, N.E. 1988. Intermountain deserts, shrub steppes and woodlands, p. 209-230. In: M.G. Barbour and W.D. Billings (eds.), North American terrestrial vegetation. Cambridge Univ. Press, New York, N.Y.

Whitford, W.G., S. Dick-Peddie, D. Walters and J.A. Ludwig. 1978. Effects of shrub defoliation on grass cover and rodent species in a Chihuahuan desert ecosystem. J. Arid Env. 1:237-242.

Zar, J.H. 1984. Biostatistical analysis, 2nd ed. Prentice-Hall, Englewood Cliffs, N.J.

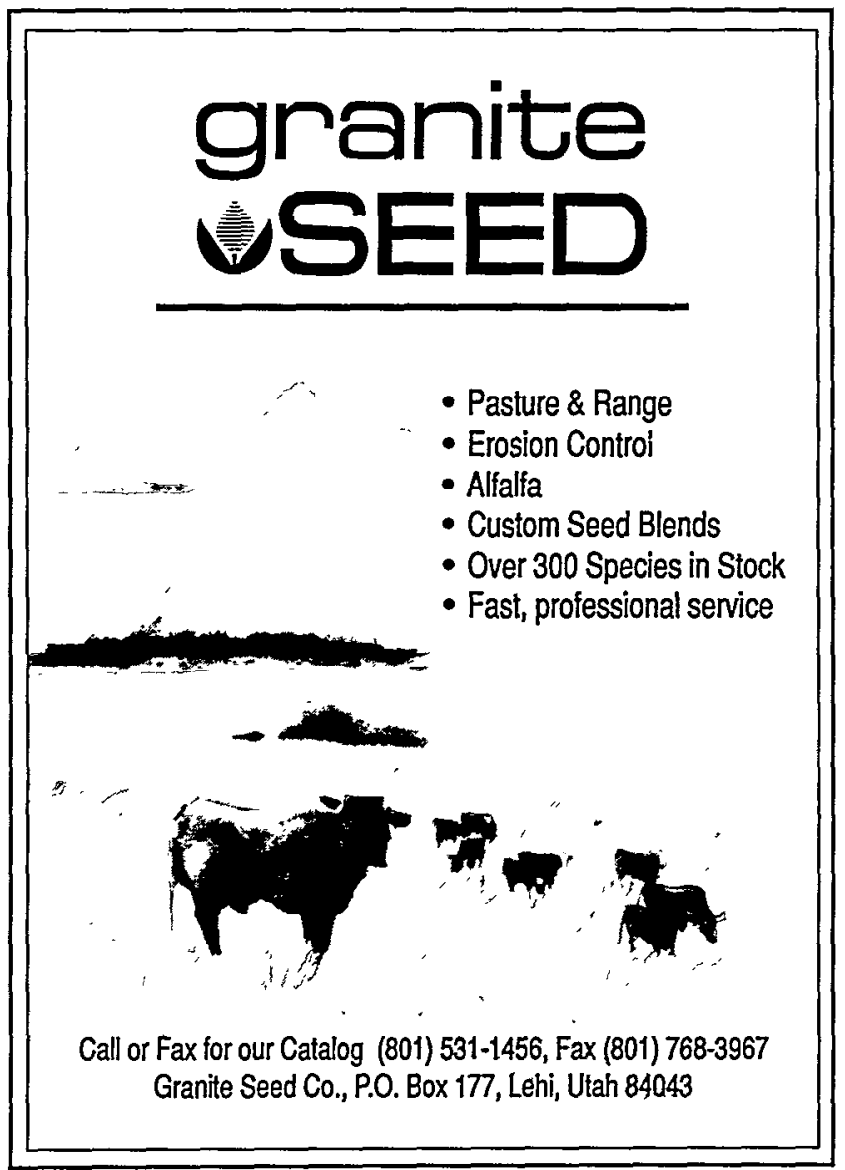

